\title{
Integrating Teams In Multidisciplinary Project Based Learning in Mechanical Engineering
}

\author{
M. Luisa Martinez, Gregorio Romero \\ Engineering Graphics \& Simulation Group \\ Universidad Politecnica de Madrid \\ ETSII - UPM. C I Jose Gutierrez Abascal 2 \\ Madrid, 28006, Spain \\ e-mail: luisa.mtzmuneta(o)upm.es
}

\author{
Juan J. Marquez, Jesus M. Perez \\ Manufacturing Group \\ Universidad Politecnica de Madrid \\ ETSII - UPM. C Jose Gutierrez Abascal 2 \\ Madrid, 28006, Spain \\ e-mail: juandejuanes.marquez@upm.es
}

\begin{abstract}
Mechanical/Industrial Engineering students at Higher Technical School of Industrial Engineering (ETSII) of Technical University of Madrid (UPM) receive an in-depth knowledge of mechanical design and manufacturing processes, but the increasing interaction with other engineering branches, induces the need to integrate concepts which allow students to make an integral design of new products, and thereby facilitate their subsequent integration into multidisciplinary engineering teams in industry.
\end{abstract}

Complex engineering projects are usually carried out by the assimilation of different work teams, which could even be located geographically distant. Collaborative Web environments are proven to be ideal knowledge repositories, as it has seen in Academia and in Industry. The work here presented reproduces the organization of actual engineering projects, and brings it into the classroom.

This new way of developing Project Work documentation and discussion has helped students become self-directed learners who internalize specific topies from different subjects, programmes and courses with their own interests, and has been considered as an easy alternative to promote active learning, not only in this area but in other courses.

Project were launched in the engineering disciplines, each offering possibilities for the application of specific skills in the following courses: TEC -Manufacturing Technology-, CAD Computer Aided Design-, SIM -Simulation in Mechanical Engineering-, and FAB -Fabrication / Manufacturing. TEC and SIM are applied in the Mechanical Engineering programme at ETSII, while FAB is part of the Industrial Engineering programme; finally $\mathrm{CAD}$ is voluntarily employed by students in different semesters and programmes. The new approach is oriented towards inducing collaboration within multidisciplinary teams.

This paper describes the experience of collaboration among students and teachers in order to develop multidisciplinary projects, and to reproduce as closely as possible, the team's integration into a company environment. A new methodology based on student interaction and content development in a Wiki environment has been developed. The collaborative server has allowed creating an "out-of-the-classroom" active discussion forum for students of different teams /topics, and to compile an important "project work" portfolio. This experience has been very satisfactory for students and teachers, who have participated with enthusiasm due to the exit of the welldistributed work and the easiness of use of the selected platform (Wiki). The quality of the developed projects has been dramatically improved due to the integration of the results provided by the different teams.

Keywords: Project Based Learning; Active Learning; Collaborative Work; Multidisciplinary Approach; Wiki Environment, Teaching Mechanical Engineering

\section{INTRODUCTION}

Mechanical/Industrial Engineering students at Higher Technical School of Industrial Engineering (ETSII) of Technical University of Madrid (UPM) receive an in-depth knowledge of mechanical design and manufacturing processes. The increasing importance of the electronics, hydraulics, pneumatics, etc. in this field induces the need to integrate multidisciplinary knowledge which will allow students to make a whole design of new products and thereby facilitate their subsequent assimilation into multidisciplinary engineering teams in industry.

The use of project-based learning that allows students to participate in complex projects was already reported quite a while ago. Examples of these experiences can be found in many areas, with a positive evaluation in the case of learning in engineering.

The main objective of this experience has been to design a set of projects to be developed by students, mainly in the area of automated engineering, where students have to work in cooperative groups of three and have to integrate their results with groups from three other different subjects. They used a Wiki server to share and prepare their work content. This server integrates the information available from all projects with the following advantages:

- "Out-of-the-classroom" discussion with the ensuing improvements in students' ability to conceptualise.

- A simple, homogeneous compilation of the documents contributed by students.

- The chance to improve knowledge in other areas of interest. 
The use of collaborative WEB environments is now commonplace in university education [1] [2]. The new technology platforms such as Blogs, Wikis and RSS feeds are proving to be invaluable educational tools that satisfy the constructivist theories of active learning [3]. Some experiences are specifically oriented towards teaching in Engineering and many are suited to collaborative work [4][5].

Some authors emphasise creating case study portfolios to promote an efficient understanding of concepts by students [6]. These case studies give rise to different ideas and have been proven to be an ideal mechanism for stimulating conceptualisation.

The Wikis are an excellent environment for a knowledge repositories and many experiences have been developed in teaching [7] [8] and in industry [9].

The use of Wikis helps improve students' reasoning abilities and their interaction with Wikis, and can be done outside the classroom as previous experiences have shown [10], where work on a collaborative project is considered as a way for students to add to the knowledge acquired in theory classes.

\section{PROJECT DEVELOPMENT}

\section{A. Team organization}

This educational initiative has been applied in four topics directly affecting 110 students working in different subjects and another 44 students that set the work for the students in each group of independent students.

The wordings for these works were launched with their particularities for the different subjects comprising the experience:

- TEC: Manufacturing Technology. (Code 1463).

- CAD: Computer Aided Design. (Code 9004).

- SIM: Simulation in Mechanical Engineering. (Code 1461).

- FAB: Manufacturing. (Code 1684).

TEC and SIM are topics in the Mechanical Engineering curriculum at the ETSII and are taught in the sixth semester while $\mathrm{FAB}$ is part of the Industrial Engineering programme taught in the eighth semester, and finally CAD is a free choice subject. Students in these subjects have carried out application projects for years but with this new experience, they are moving towards collaboration between disciplinary teams in different subjects. A collection of manufacturing cells was proposed to be worked on from four different points of view, to study and analyze them, and subsequently four different team approaches would be embraced to be solved in each of the previously mentioned topics.

This project carried out by students is shown in Figure 1 from four points of view reflected by the typical topics of these subjects and, therefore the tasks to be solved are seen from four different approaches.
Groups of three students were selected for each project and topic except for CAD which were two-student teams. Initially the teacher and students set the boundaries of the project for each topic.

The teachers involved in this experience organised fortnightly coordination meetings in order to coordinate course content timetables. Figure 2 shows an example of a problem in handling an automatic packaging machine. The difficulty of the projects proposed is uniform, but the work sequence and other specifications must be set in advance for each topic.

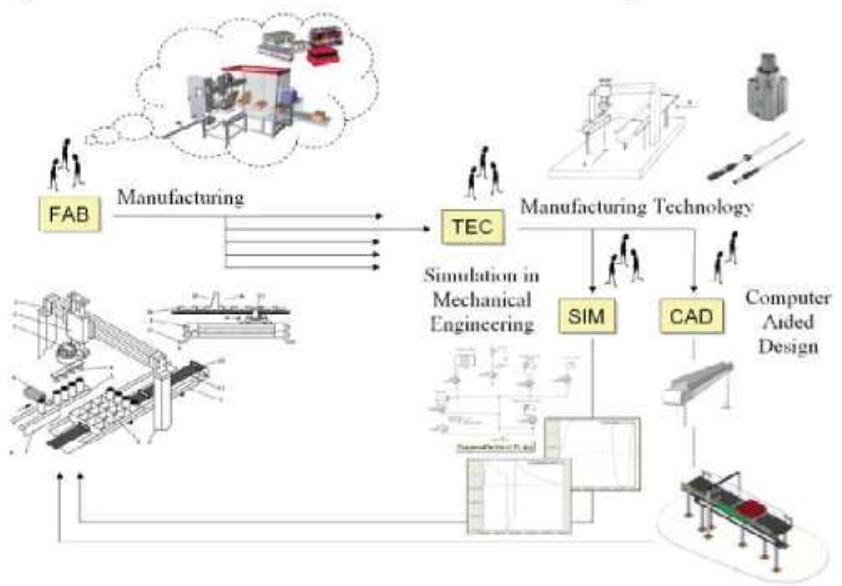

Figure 1. Four different teams for each manufacturing cell project.

Ten different types of manufacturing cells were designed. The cells proposed are shown in Table I:

TABLE I. MANUFACTURING CELLS

\begin{tabular}{|l|c|}
\hline \multicolumn{1}{|c|}{ Manufacturing cells } & Acronym \\
\hline Parts manipulation in injection molding process & DPPMI \\
\hline Machine to make pipe ending bezels & MBFT \\
\hline Panel manipulation & MP \\
\hline Can packing machine & EL \\
\hline Saw cutting unit & US \\
\hline Quality control for trays & CCB \\
\hline Glass sheets positioning & PC \\
\hline Tubular parts feeder & APT \\
\hline On demand storage feeding unit & AM \\
\hline Adhesive application station & AA \\
\hline
\end{tabular}

TABLE II. WORK EXPECTED FOR EACH TEAM:

\begin{tabular}{|c|l|}
\hline Teams & \multicolumn{1}{|c|}{ Function } \\
\hline FAB & Manufacturing process selection and planning \\
\hline TEC & Process simulation in the manufacturing cell \\
\hline SIM & Design, drawing and drafting for the manufacturing cell \\
\hline CAD & Design, drawing and drafting for the manufacturing cell \\
\hline
\end{tabular}




\section{B. Publication and development on the collaborative Web}

When each team has defined their particular area of contribution, the collaborative Web begins its task, which is basically to integrate all the information from student contributions and show it to the other teams with the purpose of enhancing the overall quality of the results produced.

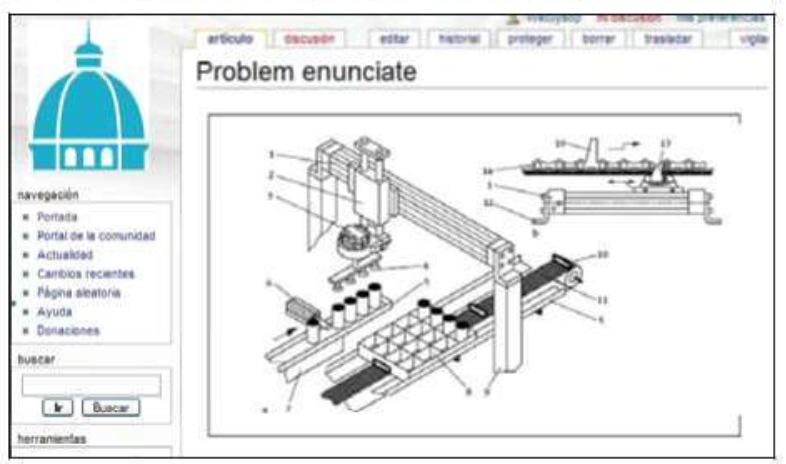

Figure 2. An example of the type of project proposed. A can packaging machine (EL). The project was provided by the teacher

To facilitate an exchange of experiences and communication among the team members assigned to developing each manufacturing cell for the different topics. Once a week they could use a collaborative classroom, where the 11 members from the different topics that had designed the manufacturing cell could exchange information face-to-face or solve problems that could not be sufficiently clarified by the Wiki.

Figure 3 shows one of these inter-group exchange classes in which the different teachers from the four topics involved answered any query and realized how the projects were progressing.

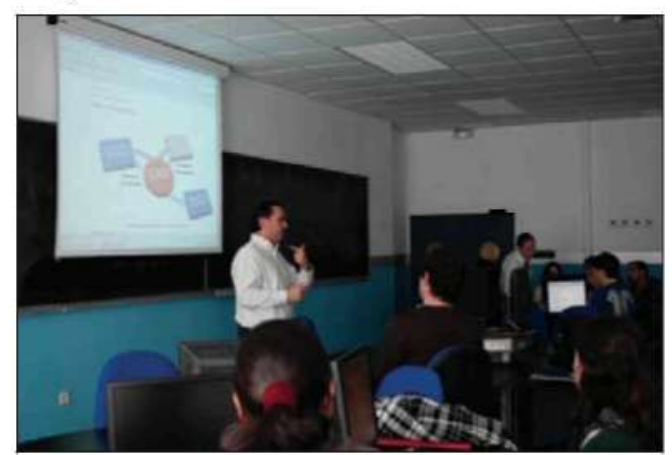

Figure 3. Team coordination meetings

In the FAB and TEC topics, the rest of the students worked to provide the main groups with information (Figure 4).

\begin{tabular}{|c|c|c|c|}
\hline \multicolumn{4}{|c|}{$\begin{array}{l}\text { Manufacturing Cell } \\
\text { (11 students) }\end{array}$} \\
\hline $\begin{array}{c}\text { CAD } \\
\text { Group } \\
\text { (2 students) }\end{array}$ & $\begin{array}{c}\text { MEC } \\
\text { Group } \\
\text { (3 students) }\end{array}$ & $\begin{array}{c}\text { FAB } \\
\text { Group } \\
\text { (3 students) }\end{array}$ & $\begin{array}{c}\text { SIM } \\
\text { Group } \\
\text { (3 students) }\end{array}$ \\
\hline & Subgroup 1 to $n$ & Subgroup 1 to $n$ & \\
\hline
\end{tabular}

Figure 4. Organization of the work groups

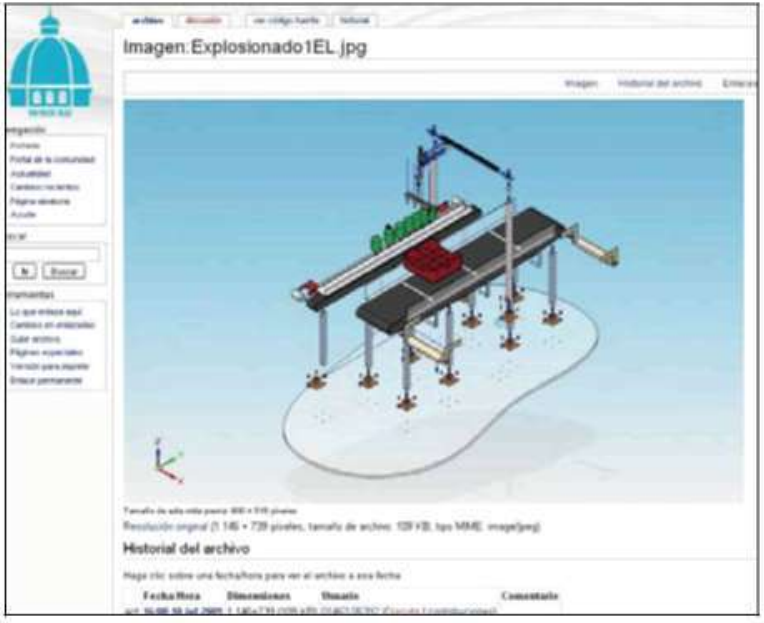

Figure 5. A preview of the wiki space for a work team; solution provided by one of the $\mathrm{CAD}$ teams about the can packing machine shown in figure 2 .

Figure 5 shows a solution to the formulation of the problem set in Figure 2 by the CAD team, chosen for publication in the so named WikiFab collaborative Web (acronym of Wiki Fabrication) [11]. MediaWiki 1.11 was chosen for its simplicity of configuration, its popularity (it is used in Wikipedia) and its powerful Wiki functionality.

In this Wiki, students must perfect the different issues set in the project. The discussion page contains everything related to working sequence and the starting conditions, such as the parts references provided by the manufacturers or the various design changes (Figure 6). All this information is discussed not only by the team members themselves but they also can receive comments from the members of other teams.

It is important to mention that the recommended format for offering solutions is a graphic format. This forces students to train their synthesis skills to express the objectives of their models through schematic outlines or diagrams. In another of the machinery stations, Figures 6 and 7 show different approaches to the proposed project model and the solution adopted respectively. The discussion page currently allows interacting with the teacher and other team members to be able to discuss the details of the proposed model.

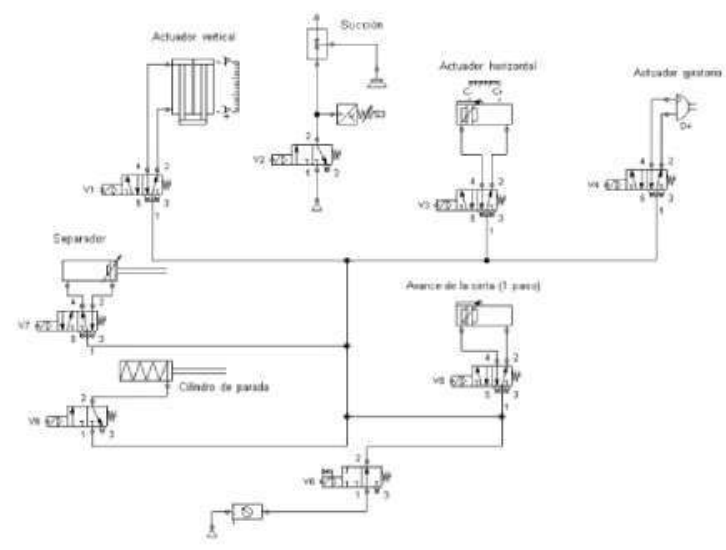

(a) 


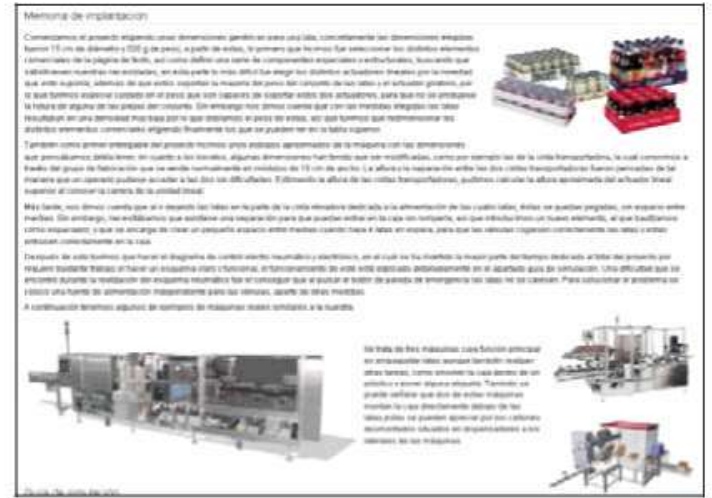

(b)

Figure 6. Different approaches to the project. (a) from the Manufacturing Technology subject TEC, (b) from the Manufacturing subject FAB.

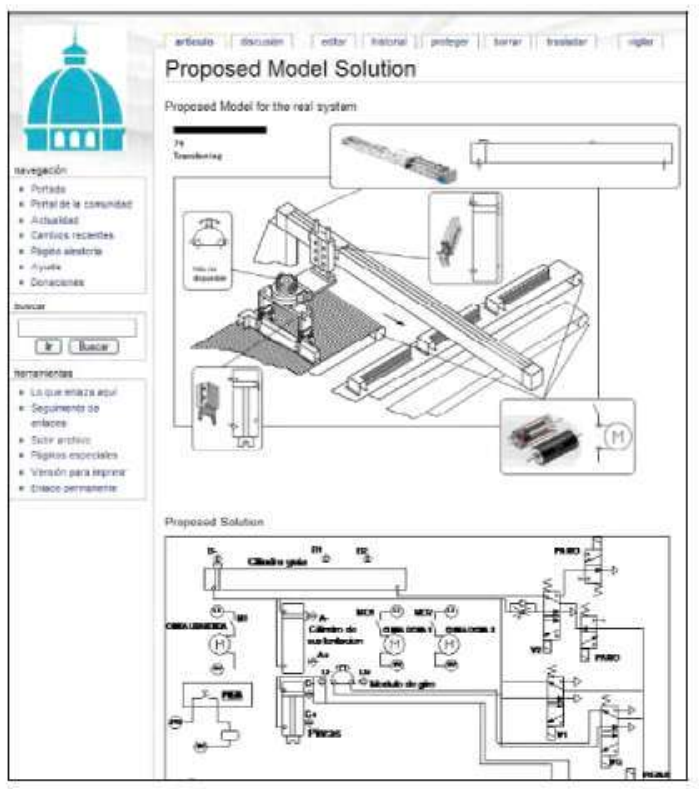

Figure 7. Solution for the proposed model

\section{RESULTS}

Every week, the students involved had to fill in a set of reports to evaluate team progress, interaction with other members and the problems they found in the assimilation of the project. These evaluation reports were prepared using Google Docs forms. Teachers use these reports to detect bad team behaviours and delays in the teamwork process.

Two general checks were also made midterm and at the end of the semester to evaluate satisfaction and the evolution of competencies.

\section{A. Influence on the marks of the subjects involved}

Figure 8 shows the average mark attained for TEC, CAD, SIM and FAB by students who took part in this experience (Project Based Learning PBL) and those who did not. It can be seen that there is difference between the two groups in the different topics as well as in the progress of the competencies developed.

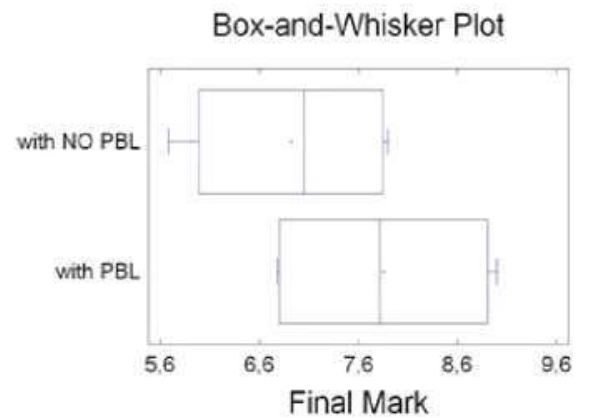

Figure 8. Comparison between students that follows the PBL method

\section{B. Follow-up checks}

Two checks were made midterm and at the end of the semester to evaluate student satisfaction. The questions contained in the survey were scored on a scale of 0 (zero) to 5 (completely in agreement). The questions were as follows (Table III):

TABLE III. CHECK QUESTIONS

\begin{tabular}{|c|l|}
\hline $\begin{array}{c}\text { Question } \\
\text { Number }\end{array}$ & \multicolumn{1}{|c|}{ Question } \\
\hline Q1 & Select your subject. \\
\hline Q2 & $\begin{array}{l}\text { The 'multidisciplinary' work method is preferable to } \\
\text { classic 'teacher-delivered lectures' }\end{array}$ \\
\hline Q3 & I think my work assessment method is correct \\
\hline Q4 & $\begin{array}{l}\text { The teacher recognises the extra effort required to do } \\
\text { work outside the classtoom }\end{array}$ \\
\hline Q5 & $\begin{array}{l}\text { The effort made to take part in the project is } \\
\text { worthwhile. It would be a mistake not to take part in } \\
\text { this experience. }\end{array}$ \\
\hline Q6 & Would you recommend it to a friend? \\
\hline Q7 & Score the WikiFab enviroment \\
\hline Q8 & $\begin{array}{l}\text { I have improved my ability to work in } \\
\text { multidisciplinary teams }\end{array}$ \\
\hline Q9 & I can estimate work execution times more accurately \\
\hline Q10 & I am more precise in the work I do \\
\hline Q11 & $\begin{array}{l}\text { I have improved my ability to work with different } \\
\text { teams by having to exchange information } .\end{array}$ \\
\hline Q12 & I have more leadership ability \\
\hline
\end{tabular}

Q6 has no numeric answer, the responses could be 'Yes', 'No', or 'I don't know'.

\section{Statistical analysis}

The results of these surveys were analysed statistically, obtaining the findings described below. 154 students answered the surveys: 23 students were enrolled in the CAD subject, 53 students applied in FAB topic, 28 students were working in SIM and 50 students in FAB.

Figure 9 reflects how at the end of the semester the scores for satisfaction showed a perceived improvement in competencies, although not in a major way, since from the start of the programme students perceive a positive improvement in their competencies. The multidisciplinary method used compared to the traditional one is scored favourably (Q2). 


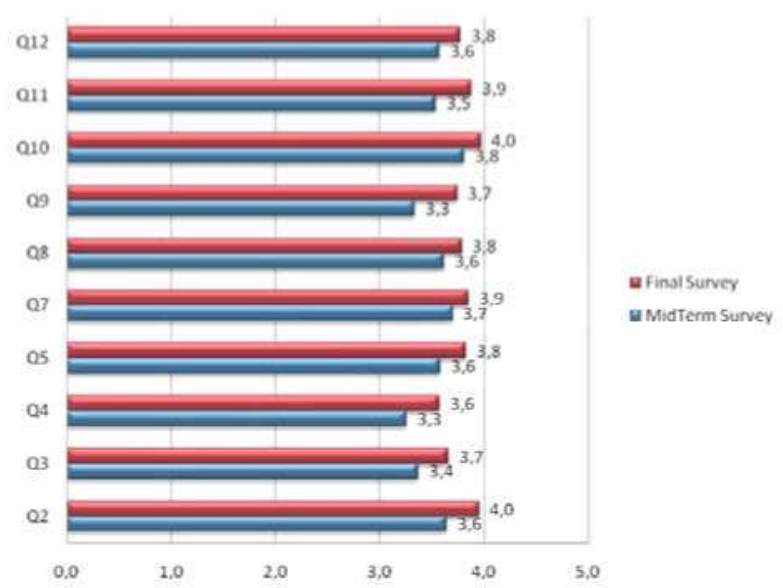

Figure 9. Mean of the questions results for $\mathrm{Q} 2$ to $\mathrm{Q} 12$

It can also be seen that there are no important deviations in the sample taken (Figure 10):

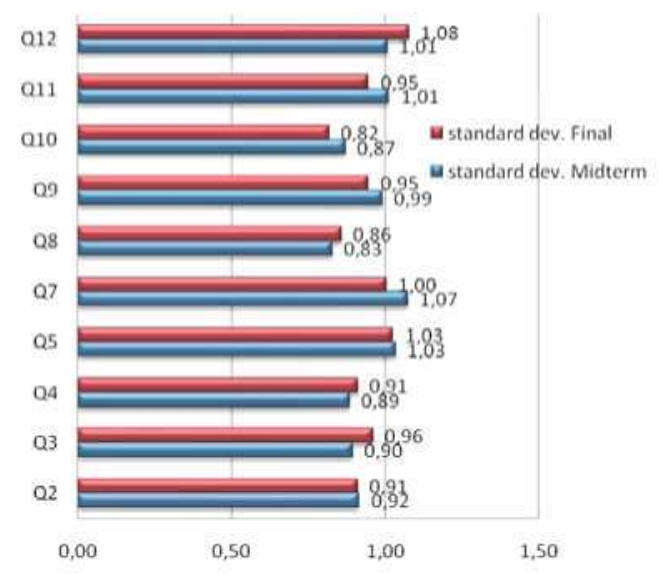

Figure 10. Standard deviations for Q2 to Q12 results

Regarding question Q6 "Would you recommend it to a friend?" the following results were obtained. It can be seen how in midterm students are doubtful of the benefits of the programme. However, at the end they are satisfied (Figure 11).

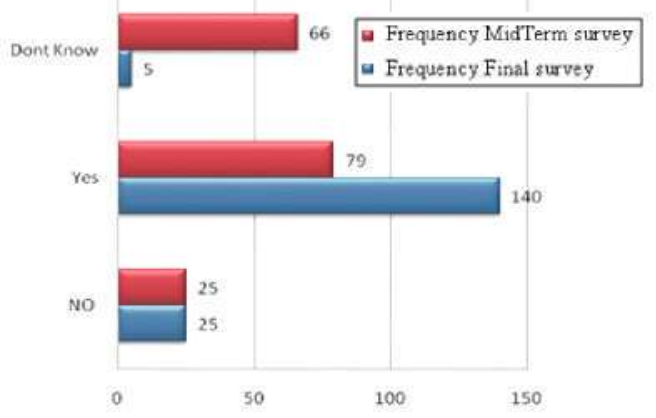

Figure 11. Histogram corresponding to Q6 results.

Chi-square test were made and ' $\mathrm{P}$-value $=0$ ' $(<0,1)$ so we can reject the hypothesis that rows and columns are independent at the $99 \%$ confidence level.
Therefore, the observed value of Q6 (fig. 11) in the midterm survey is related to its value for its subject.

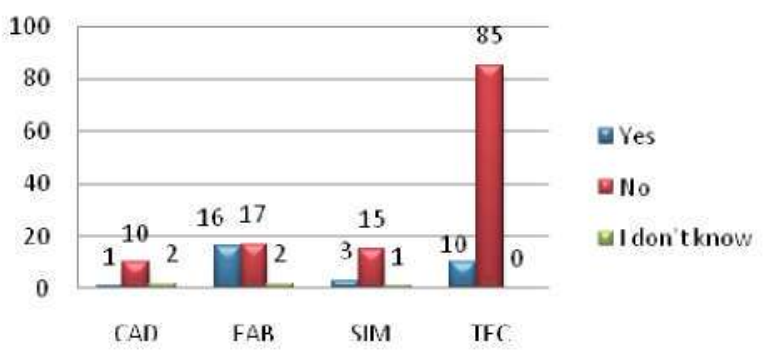

Figure 12, Q6 results in the midterm survey

This Q6 question was studied in the final survey again obtaining a clear correlation with the topic's students belong. Performing the Chi-square test, Since the P-value $=0,0056$ is less than 0.01 , we may reject the hypothesis that rows and columns are independent at the $99 \%$ confidence level. Therefore, the observed value of Q6 in the final survey case is related to its value for the applied subject.

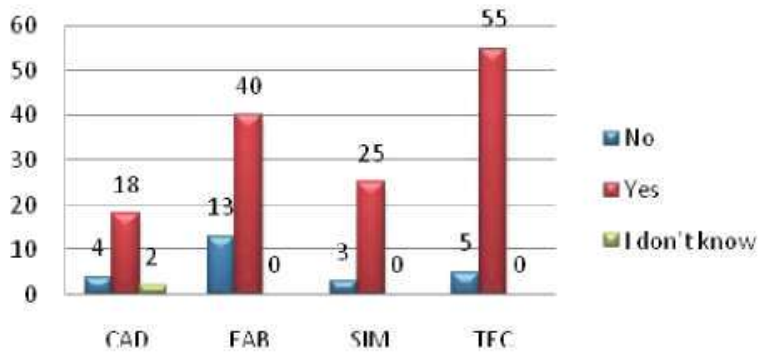

Figure 13. Q6 results in the final survey

D. Analysis by subject

An ANOVA analysis was made of the different student opinions regarding the topic they were studying. These findings refer to the final survey conducted in the semester.

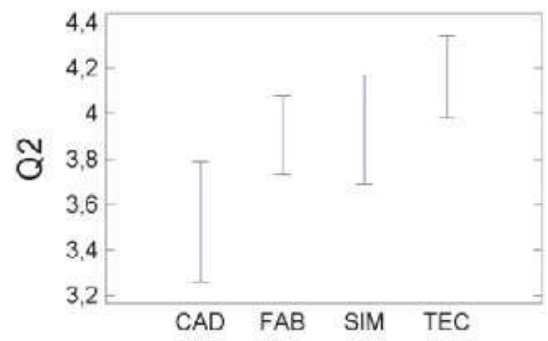

Figure 14. ANOVA(means and 95,0 Percent LSD Intervals) of Q2 results

The response to Q2 shows discrepancies between the CAD and TEC groups (Figure 14). We use the Student t-test to know if the groups are or not are homogeneous.

The responses to Q3 and Q4 show a homogeneous distribution for all groups. The response to Q5 shows discrepancies between the $\mathrm{FAB}$ and TEC groups. The $\mathrm{FAB}$ students do not positively score the extra effort required compared to multidisciplinary work. 
On the other hand, these students are from the Industrial Organization specialisation and are not purely Mechanical Engineers (Figure 15).

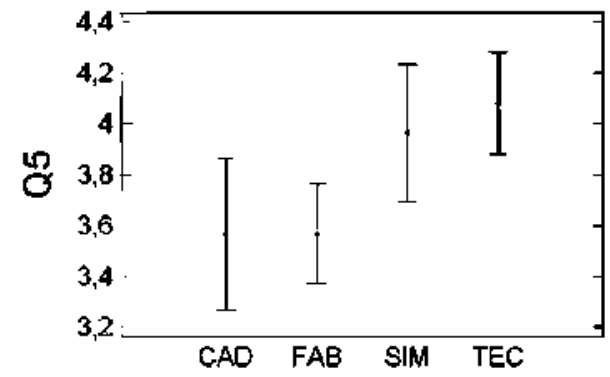

Figure 15. ANOVA (means and 95,0 Percent LSD Intervals) of Q5 results

However, question Q7 did show more disparate performance as Figure 16 shows. The SIM and TEC students score it very positively, which was not the case with the other groups.

The SIM students found the Wiki to be a very useful environment for developing their work and the TEC group, moreover, was driven by a teacher who was highly enthusiastic about its use and deployment.

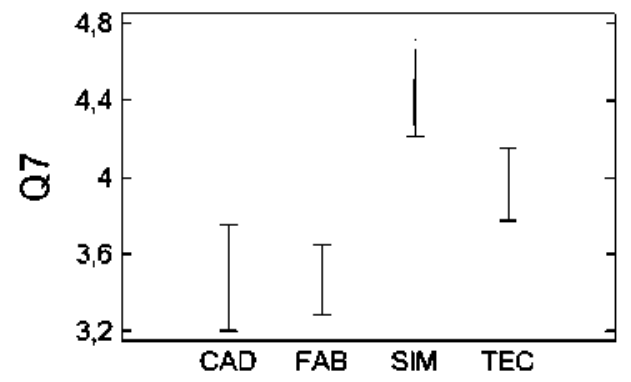

Figure 16. ANOVA (means and 95,0 Percent LSD Intervals) of Q7 results

The CAD students did not perceive any improvement in their work in multidisciplinary teams (Q8) compared to the other groups (Figure 17).

The TEC and FAB groups considered they had improved their time calculation estimates for jobs $(Q 9)$ better than the other teams (Figure 18).

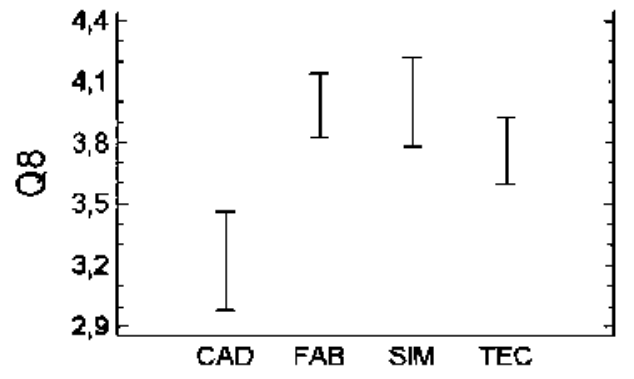

Figure 17. ANOVA (means and 95,0 Percent LSD Intelvals) of Q8 results

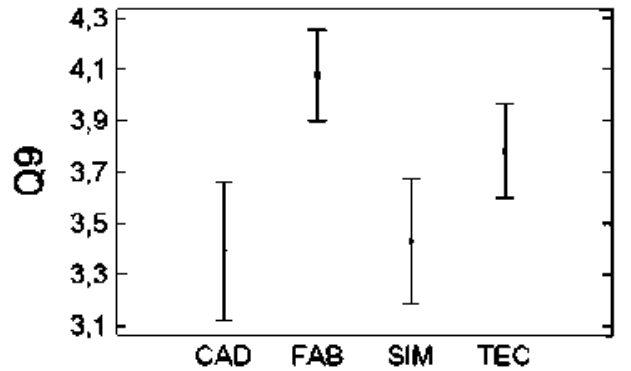

Figure 18. ANOVA (means and 95,0 Percent LSD Intervals) of Q9 results

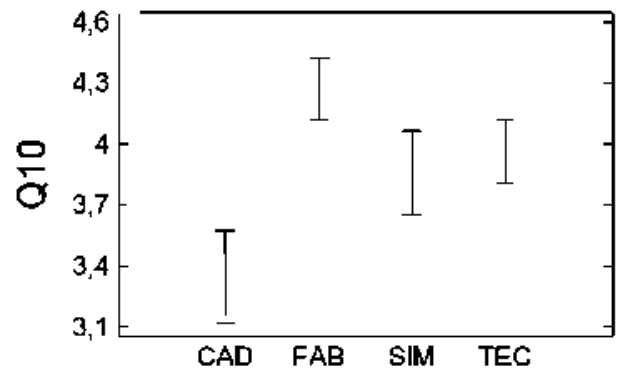

Figure 19. ANOVA (means and 95,0 Percent LSD Interv.) of Q10 results

Regarding Q11, the ability to exchange information was compared to other teams. All the means were above 3.5 points with the $\mathrm{FAB}$ teams giving the highest scores (Figure 20 ).

The FAB teams best score leadership ability (Q12). The CAD teams do not consider they have improved their leadership abilities (Figure 21).

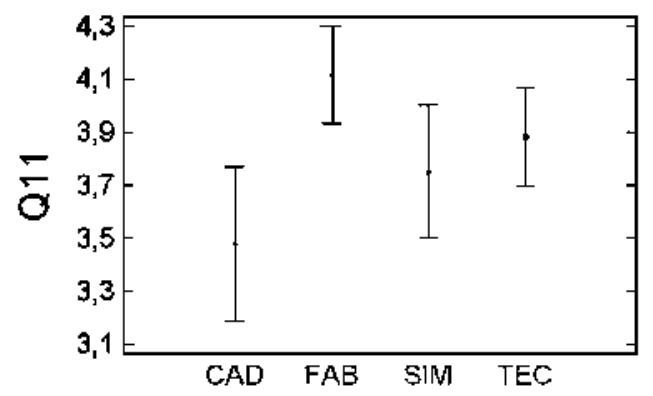

Figure 20. ANOVA (means and 95,0 Percent LSD Interv.) of Q11 results

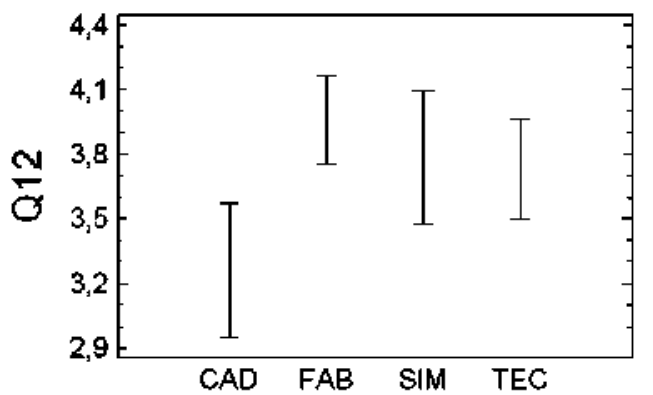

Figure 21. ANOVA (means and 95,0 Percent LSD Interv.) of Q12.results 


\section{CONCLUSIONS}

We have presented an experience for a large number of students involved in four topics from two different specialisations related to the Mechanical Engineering course of the Industrial Engineering degree. The use of a collaborative Web environment has made it possible for students to work in multidisciplinary teams. Students analyse, reason, discuss and decide on the solutions that their companions keep suggesting until completion of the project. This project has enabled students to approach a problem from four different points of view and mould them to the opinions of the other contributions from different subjects.

This new way of carrying out the project in this paper and its subsequent discussion has been very enthusiastically received by the student body and the teaching staff who consider it a simple alternative for promoting collaborative tasks between different groups.

The Web structure will let a major set of automated manufacturing case studies to be collected in a homogeneous format that may well become a virtual reference space in this area.

\section{ACKNOWLEDGEMENTS}

This work was financed by the Office of the Vice Provost for Academic Organization and Strategic Planning of the Universidad Politécnica de Madrid (UPM) as part of the 2008 Educational Innovation Programme, with number IE08052578.

\section{REFERENCES}

[1] Realff, M., Ludovice, P., Guzdial, M., 2000, "Computer Supported Collaborative Leaming for Cuniculum Integration," Computers \& Chemical Engineering, 24(2-7) pp. 1473-1479.

[2] Hao-Chuan Wang, 2005, "An Empirical Exploration of using Wiki in an English as a Second Language Course," Advanced Leaming Technologies, 2005. ICALT 2005. Fifth IEEE Intemational Conference o11, Pp. 155-157.

[3] Notari, M., 2006, "How to use a Wiki in education: 'Wiki based effective constructive learning." Proceedings of the 2006 international symposium on Wikis, ACM, pp. $131-132$

[4] Chao, J., 2007, "Student Project Collaboration using Wikis," 20th Conference on Software Engineering Education \& Training, Proceedings, pp. 255-261.

[5] Chun, A. H. W., 2004, "The Agile Teaching," Advances in Web-Based Leaning - Icwl 2004, 3143pp. 11-18.

[6] Eris, 0., 2006, "Insisting on Truth at the Expense of Conceptualization: Can Engineering Portfolios Help?" International Jounial of Engineering Education, 22(3) pp. 551-559.

[7] John, M., and Melster, R., 2004, "Knowledge Networks - Managing Collaborative Knowledge Spaces," Advances in Lealning Software Organizations, Proceedings, 3096pp. 165-171.

[8] Hu, C. P., Zliao, Y., and Zhao, X. Q., 2007, "Wiki-Based Knowledge Sharing in a Knowledge-Intensive Organization," Integration and Innovation Orient to E-Society, Vol 2, 252pp. 18-25.

[9] Chan, T., and Maurer, F., 2005, "A case study of wiki-based experience repository at a medium-sized software company," Proceedings of the 3rd intenuational conference on Knowledge capture, ACM, pp. 185-186.

[10] Wodehouse, A., Eris, O., Grierson, H., 2007, "Enhancing Design Learming using Groupware," International Journal of Engineering Education, 23(3) pp. $557-569$.

[11] WikiFab: http://138.100.80.137/wikifab/index.php/MULTIPIE_2008-09 